\title{
Rancang Bangun Perangkap Hama Serangga Pada Padi dengan Sumber Sel Surya \\ (Studi Kasus: Rama Otama 1, Seputih Raman, Lampung Tengah, Lampung)

\author{
Novia Utami Putri ${ }^{1}$, I Putu Angga Saputra ${ }^{2}$, Fika Trisnawati ${ }^{3}$ \\ Jurusan Teknik Elektro Universitas Teknokrat Indonesia, Bandar Lampung \\ Jl. ZA. Pagar Alam No.9 -11, Labuhan Ratu, Kec. Kedaton, Kota Bandar Lampung, Lampung 35132 \\ noviautamieteknokrat.ac.id
}

Intisari - Pada daerah persawahan biasanya terdapat banyak hama serangga yang dapat membuat para petani mengalami gagal panen. Petani padi di Desa Rama Otama I biasanya menggunakan pestisida untuk membasmi hama, tetapi penggunaaan pestisida secara berlebihan dapat merusak tanaman padi itu sendiri karena pestisida mengandung bahan kimia. Penelitian ini bertujuan untuk merancang alat pembasmi hama padi menggunakan jaring - jaring kawat bertegangan dengan sumber energi sel surya,prinsip kerja alat ini yaitu dengan mengecas baterai pada siang hari dengan bantuan sel surya, sel surya mempunyai fungsi yaitu dapat merubah energi matahari menjadi energi listrik kemudian dari baterai di hubungkan dengan Inverter yang dapat merubah listrik DC menjadi listik AC sehingga saat malam hari dapat menghidupkan lampu dan jaring - jaring kawat secara otomatis menggunakan timer theben yang sudah di setel. Pengujian alat ini dilakukan selama 7 hari dimulai dari pukul 06.00 - 18.00 untuk mengecas baterai, daya yang dihasilkan terbesar yaitu hari ke-2 pada pukul 11:00 WIB dengan daya sebesar 126,132 Watt, tegangan pada hari ke-2 yaitu sebesar 23,6 V dan arus sebesar 6,87 A., sedangkan pada pukul 18.00 - 06.00 lampu dan jaring - jaring kawat bekerja dan pada pukul tersebut hama serangga mulai beraktivitas sehingga banyak hama serangga yang terbunuh oleh jaring - jaring kawat. Jenis hama yang terbunuh oleh jaring - jaring yaitu hama wereng, walang sangit, lembing, dan kupu - kupu sundep.

Kata kunci - Hama Serangga, Pestisida, Sel Surya, Jaring-jaring kawat.

Abstract - In rice fields there are usually many insect pests that can make farmers experience crop failure. Rice farmers in Rama Otama I Village usually use pesticides to eradicate pests, but excessive use of pesticides can damage the rice plants themselves because pesticides contain chemicals. This study aims to design a rice pest control device using a voltage wire net with a solar cell energy source, the working principle of this tool is to charge the battery during the day with the help of solar cells, solar cells have a function that is to convert solar energy into electrical energy then from the battery it is connected to an inverter which can convert DC electricity to $\mathrm{AC}$ electricity so that at night it can turn on the lights and wire nets automatically using the theben timer that has been set. The test of this tool was carried out for 7 days starting from $06.00-18.00$ to charge the battery, the largest power produced was on the 2nd day at 11:00 WIB with a power of 126.132 Watt, the voltage on the 2nd day was $23.6 \mathrm{~V}$ and a current of $6.87 \mathrm{~A}$., while at $18.00-06.00$ the lights and wire nets worked and at that time the insect pests began to move so that many insect pests were killed by the wire nets. The types of pests killed by the nets were leafhoppers, walang sangit, javelin, and sundep butterflies.

Keywords - Insect Pests, Pesticides, Solar Cells, Wire nets. 


\section{PENDAHULUAN}

Padi merupakan makanan pokok hampir setengah penduduk dunia di mana sebagian besar berasal dari negara berkembang termasuk Indonesia [1]. Banyak usaha yang telah dilakukan oleh pemerintah untuk meningkatkan produktivitas padi, walaupun selalu mendapat hambatan. Panen menurun karena serangannya pada bagian akar, batang, daun, maupun bulir padi [2]. Kemunculan hama pada pertanian merupakan perihal yang untuk diperhatikan secara serius. Terganggunya stabilitas produksi pertanian tentu berpengaruh perekonomian dan akan memepengaruhi segala sendi kehidupan bermasyarakat. Hama merupakan musuh para petani, kmunculan hama pada areal persawahan akan mengganggu stabilitas pertumbuhan tanaman [3]. Oleh karenanya perlu dilakukan tindakan pencegahan agar dampak dari hama pertanian tidak semakin memperburuk.

Kabupaten Lampung Tengah, Kecamatan Seputihraman, Desa Rama Otama Satu, sangat terganggu akan kemunculanya hama wereng, walang sangit, namun ada persoalan pokok yang dihadapi petani dalam memproduksi 2 padi menjadi beras adalah gagal panen akibat serangan hama serangga pada padi. Hama serangga selain merusak kualitas padi hama walang sangit juga mengeluarkan aroma khas yang bau [4]. Hal ini mengakibatkan kerugian yang cukup besar baik berupa kehilangan hasil, penurunan mutu, terganggunya produksi, serta penurunan pendapatan petani, untuk mengatasi hama seperti wereng,walang sangit, dan hama pada tanaman padi [5]. Salah satu sifat serangga adalah memiliki ketertarikan pada cahaya. Intensitas cahaya dapat berpengaruh pada perilaku hama serangga yang mana penangkapan hama tersebut dapat dimanfaatkan dalam bidang pertanian pengendalian hama [6]. Kemampuan ini dapat dijadikan alat pengendalian populasi serangga atau hama yang tidak menguntungkan dengan pendekatan ramah lingkungan [7].

Berdasarkan permasalahan yang diatasi peneliti ingin merancang bangun perangkap hama serangga pada padi dengan sumber sel surya, sedangkan untuk eksekusi dari hama wereng,walang sangit menggunakan jarring jaring kawat yang nantinya hama wereng, walangsangit akan tersengat ketika menyentuh jaring - jaring kawat bertrgangan, namun ada tempat atau wadah yang berguna untuk menampung hasil hama wereng, walang sangit yang sudah tersengat atau mati Harapannya, alat ini dapat diaplikasikan sehingga bebas dari dampak 3 negatif penggunaan bahan kimia atau pestisida dengan menghemat energy yang dibutuhkan serta dapat meningkatkan produktivitas hasil panen padi.

\section{METODE}

\section{A. Metode Pengumpulan Data}

Lokasi pengujian alat pada Desa Seputih Raman, Raman Otama 1, Lampung tengah, Lampung. Adapun metode yang penelitian yang digunakan adalah sebagai berikut :

1) Studi Literatur

Studi litenatur ini dilakukan untuk memahami pengetahuan bagi peneliti dan menambah refrensi bahan dalam merancang dan membuat alat perangkap hama serangga padi tenaga surya.

2) Studi Konsultasi

Adapun dalam proses penyelesaian tugas akhir ini penulis terlebih dahulu melakukan konsultasi dengan dosen pembimbing mengenai perancang alat ini.

3) Studi Perancangan Sistem

Merancang dan membuat alat perangkap hama serangga padi tenaga surya menggunakan timer theben sul $181 \mathrm{~h}$.

4) Studi Pengujian Alat dan Analisa

Menguji dan menganalisa perangkap hama serangga pada padi tenaga surya menggunakan timer theben sul $181 \mathrm{~h}$ apakah alat bekerja dengan baik, lalu penganalisaan dilakukan dengan cara membandingkan hama terperangkap disetiap harinya, menganalisis penggunaan daya harian.

\section{B. Perancangan Mekanik}

Desain mekanis dari perangkap hama serangga pada padi tenaga surya dapat di lihat pada gambar 1 berikut ini : 


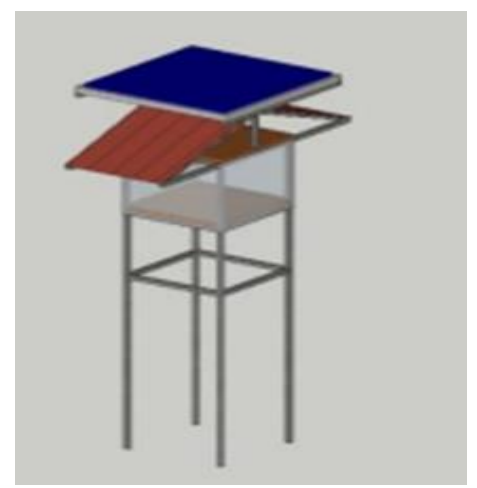

Gbr 1. Desain Mekanik Alat

Adapun langkah untuk perancangan mekanik perangkap hama serangga pada padi tenaga surya yaitu pemilihan bahan yang akan digunakan untuk kerangka. Setelah bahan didapat, dibentuklah susunan daribahan tersebut untuk menjadi kerangka alat perangkap hama serangga pada padi tenaga surya. Desain dari kerangka dibuat kokoh agar dapat menahan beban dari masing - masing komponen.

Adapun diagram alir penelitian dapat dilihat pada gambar 2 dibawah ini :

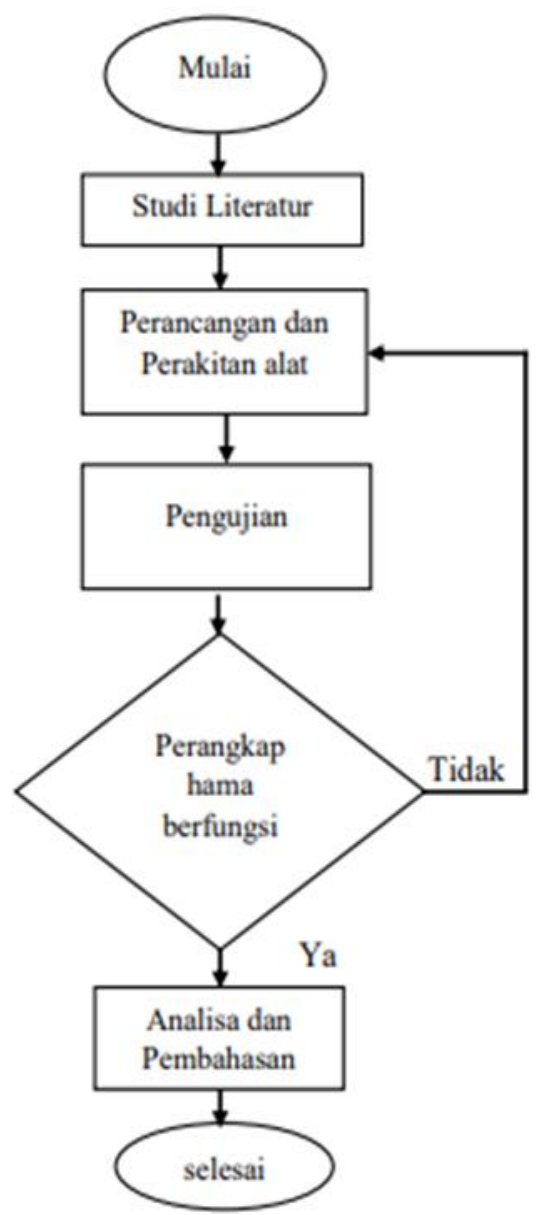

Gbr 2. Diagram Alir penelitian
Diagram alir penelitan yang akan dilakukan dapat dilihat pada gambar 3.3, diawali dengan perancangan alat, pembuatan alat serta dilanjutkan pengujian alat secara keseluruhan. Penelitian ini bertujuan untuk mengurangi pemakaian bahan kimia atau pestisida. Diagram alir cara kerja alat dapat dilihat pada gambar 3 dibawah ini :

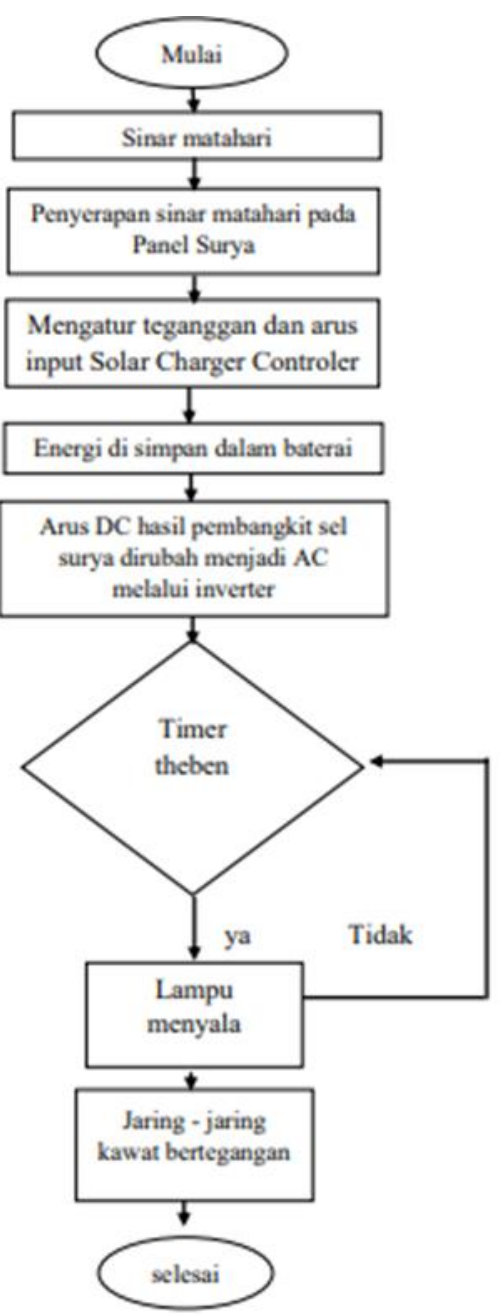

Gbr 3. Diagram Alir Cara Kerja Alat

III. HASIL DAN PEMBAHASAN

\section{A. Pengujian Panel Surya}

Pada tahap ini pengujian alat dilakukan ada daerah persawahan penduduk yang beloksi di Desa Rama Otama 1, Kecamatan Seputih Raman,Lampung Tengah. Alasan pengujian dilakukan di Desa Rama Otama 1, Kecamatan Seputih Raman,Lampung Tengah dikarenakan mayoritas pendudukadalah petani, selain itu di daerah tersebut masih banyak petani yang mengeluhkan tentang adanya hama pada padi yang membuat 
kegagalan dalam panen. Hasil muatan panel surya dapat dilihat pada tabel 1 dibawah ini.

Tabel 1. Nilai Voc Dan Isc

\begin{tabular}{|c|c|c|}
\hline Jam & Vcc & Isc \\
\hline 06.00 & 17,2 & 0,61 \\
\hline 07.00 & 22,9 & 1,14 \\
\hline 08.00 & 22,6 & 2,6 \\
\hline 09.00 & 23,1 & 4,78 \\
\hline 10.00 & 23,2 & 5,7 \\
\hline 11.00 & 23,3 & 6,99 \\
\hline 12.00 & 23,2 & 6,6 \\
\hline 13.00 & 23,8 & 6,34 \\
\hline 14.00 & 23,5 & 5,83 \\
\hline 15.00 & 22,9 & 2,51 \\
\hline 16.00 & 22,4 & 1,26 \\
\hline 17.00 & 21,3 & 0,43 \\
\hline 18.00 & 8,6 & 0 \\
\hline
\end{tabular}

Spesifikasi panel surya yang digunakan pada penelitian ini dapat dilihat pada gambar 4 dibawah ini.

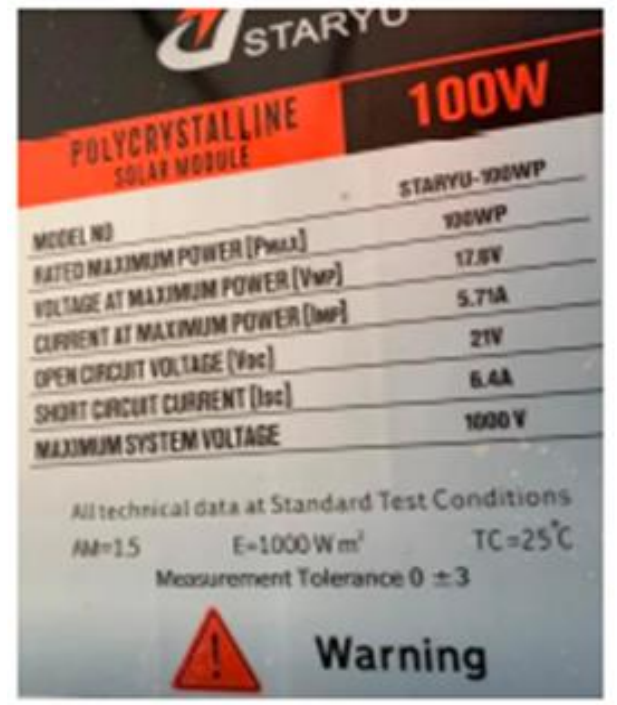

Gbr 4. Spesifikasi panel surya

Pada tabel 1 dapat dilihat Voc tertinggi yaitu 23,8 Volt dan Isc tersebsar yaitu 6,99 A dibandingkan dengan gambar 4 spesifikasi panel bahwa Voc sebesar 21 Volt dan Isc sebesar 6,4A sehingga dapat disimpulkan bahwa panel surya bekerja dengan baik sesuai dengan spesifikasi.

\section{B. Pengujian Jaring-Jaring Kawat \\ Bertegangan}

Pengujian jaring - jaring kawat bertegangan bertujuan untuk mengetahui apakah jaring - jaring kawat dapat menyengat pada hama pada tanaman padi, pengujian dilakukan dengan cara melemparkan hewan jangkrik. Melemparkan jangkrik dapat dilihat pada gambar 5 .

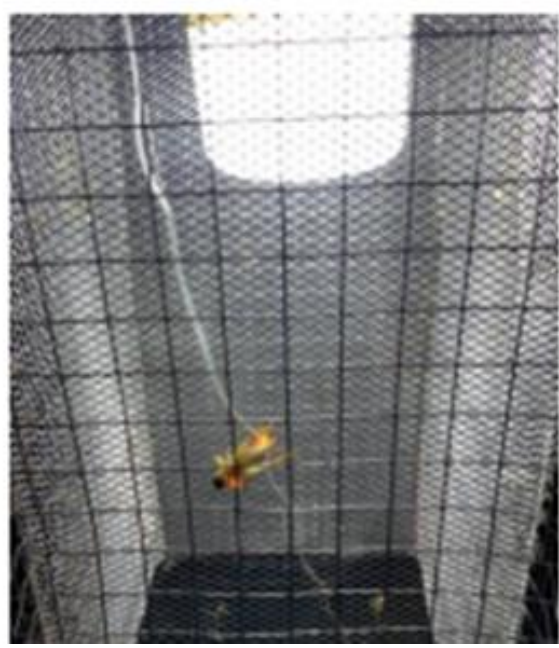

Gbr 5. Jangkrik Tersengat Listrik

Pada gambar 5 dapat dilihat bahwa jangkrik yang dilemparkan pada jaring jaring kawat bertegangan tersengat sehingga terbunuh.

\section{Pengujian Alat}

Pengujian keseluruhan alat yaitu dilakukan setelah nelakukan pengujian seluruh alat, pengujian keseluruhan alat ini berfungsi untuk mengetahui apakah alat bekerja dengan baik. Pengujian ini melihat apakah panel surya dapat mengecas baterai dengan penuh sehingga dapatmenghidupkan lampu dan menghidupkan jaring - jaring kawat yang bertegangan listrik dapat menyengat hama hingga terbunuh. Pengecasan baterai mulai pukul 06.00 WIB sampai 18.00 WIB dapat dilihat pada gambar 6 .

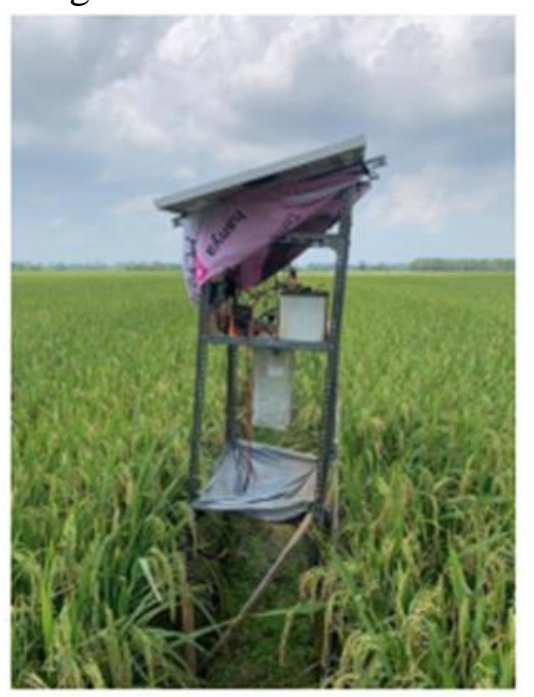

Gbr 6. Pengecasan alat saat siang hari 
Pada pukul 19.00 WIB timer theben bekerja untuk menyalurkan listrik dari baterai melalui inverter yang merubah tegangan baterai dari 12 volt menjadi 220 volt yang disalurkan ke beban sehingga beban lampu dan jaring - jaring kawat bertegangan menyala untuk menyengat hama hingga mati. Lampu dan jaring - jaring kawat menyala pada malam hari dapat dilihat pada gambar 7 .

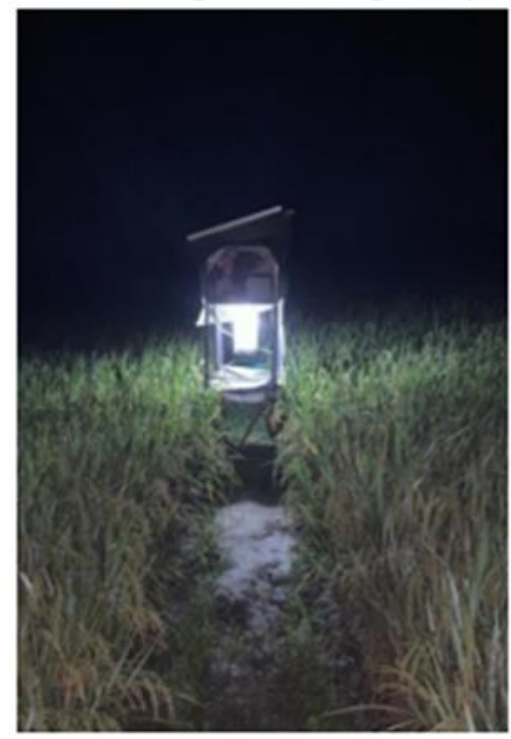

Gbr 7. Pengujian alat pada saat malam hari

\section{Pembahasan}

Pada penelitian ini hasil dan pembahasan berisi hasil dari penelitian selama 7 hari data yang diambil berupa data tegangan, arus, dan perhitungan daya pada input panel surya. Data berupa tegangan, arus dan perhitungan daya pada output baterai, setelah itu data data tersebut di bahas sehingga dapat dilihat kinerja dari alat pengusir hama menggunakan jaring - jaring kawat bertegangan. Hasil penelitian pada hari ke tujuh dapat dilihat pada tabel 2 dibawah ini :

Tabel 2. Hasil Penelitian Pada Hari Ke Tujuh

\begin{tabular}{|l|c|c|l|l|l|r|}
\hline \multirow{2}{*}{ Jam } & \multicolumn{3}{|c|}{ Input panel surya } & \multicolumn{3}{c|}{ Output baterai } \\
\cline { 2 - 7 } & $\mathrm{V}$ & $\mathrm{I}$ & \multicolumn{1}{c|}{$\mathrm{W}$} & $\mathrm{V}$ & $\mathrm{I}$ & $\mathrm{W}$ \\
\hline 06.00 & 13,6 & 0 & 0 & 12,7 & 2,7 & 34,29 \\
\hline 07.00 & 20,4 & 0,51 & 10,404 & 12,5 & 2,7 & 33,75 \\
\hline 08.00 & 22,3 & 1,24 & 27,528 & 12,4 & 2,7 & 33,48 \\
\hline 09.00 & 22,8 & 3,4 & 77,52 & 12,4 & 2,7 & 33,48 \\
\hline 10.00 & 24,2 & 1,32 & 31,944 & 12,3 & 2,7 & 33,21 \\
\hline 11.00 & 22,5 & 6,78 & 152,55 & 12,3 & 2,7 & 33,21 \\
\hline 12.00 & 22,5 & 6,27 & 141,075 & 12,2 & 2,7 & 32,94 \\
\hline 13.00 & 21,7 & 1,05 & 22,785 & 12,1 & 2,7 & 32,94 \\
\hline 14.00 & 21,9 & 0,95 & 20,805 & 12,1 & 2,7 & 32,67 \\
\hline 15.00 & 22 & 0,75 & 16,5 & 12 & 2,7 & 32,67 \\
\hline 16.00 & 21,7 & 0,65 & 14,105 & 12 & 2,7 & 32,4 \\
\hline 17.00 & 19,7 & 0,16 & 3,152 & 12 & 2,7 & 32,4 \\
\hline 18.00 & 5,1 & 0 & 0 & 12 & 2,7 & 32,4 \\
\hline
\end{tabular}

Pada Tabel 2 disajikanya nilai input panel surya berupa tegangan, arus dan daya berfungsi untuk mengetahui efisiensi pengecasan baterai, dan disajikan juga output baterai berupa tegangan, arus dan daya berfungsi untuk mengetahui kinerja alat pada malam hari untuk menghidupkan lampu dan jaring - jaring kawat bertegangan. Tegangan tertinggi pada jam 10:00 memiliki nilai tegangan sebesar $24,2 \mathrm{~V}$, dan memiliki nilai tegangan terendah $5,1 \mathrm{~V}$ pada jam 18:00 dikarenakan pada sore hari matahari sudah tidak ada sehingga panel tidak terpancarkan sinar matahari. Memiliki arus terbesar pada jam 11:00 memiliki nilai 6,78 A serta memiliki nilai terkecil 0 A pada jam 18:00 dikarenakan panel surya sudah tidak terpancar sinar matahari. Pada jam 18.00 panel surya masih terdapat tegangan tetapi arus pada panel $0 \mathrm{~A}$ dikarenakan panel surya tidak mendapatkan sinar matahari sehingga menyebabkan panel surya masih terdapat tegangan tetapi tidak ada arus.

Berikut ini jenis-jenis hewan yang tertarik pada alat perangkap hama padi adalah :

1) Hama lembing

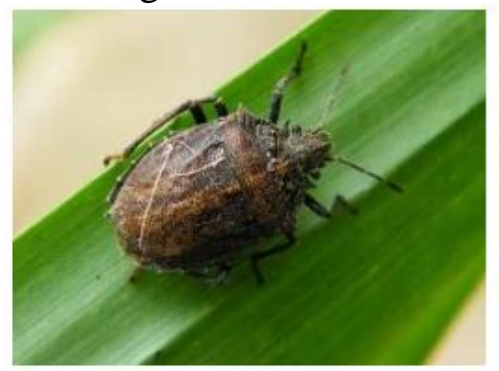

Gbr 7. lembing

2) Hama wereng

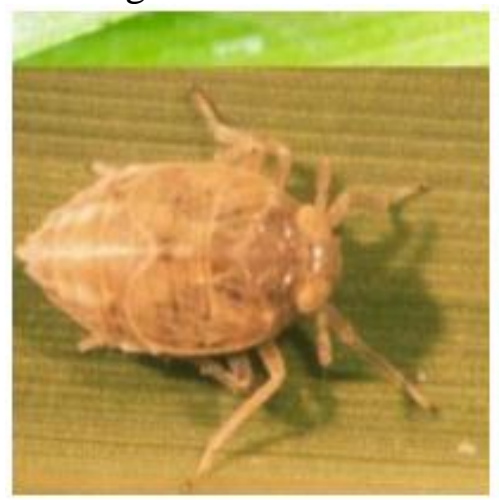

Gbr 8. Wareng 
3) Hama walang sangit

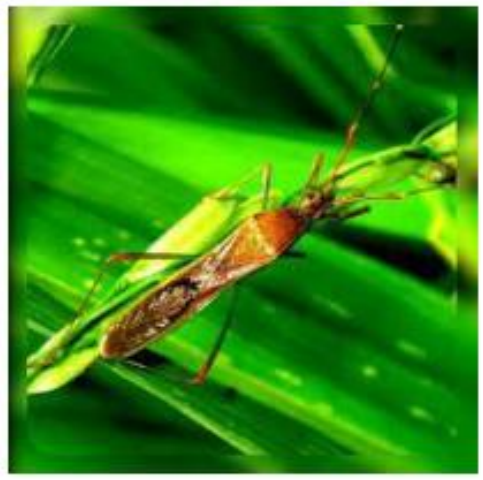

Gbr 9. Walang sangit

4) Hama sundep

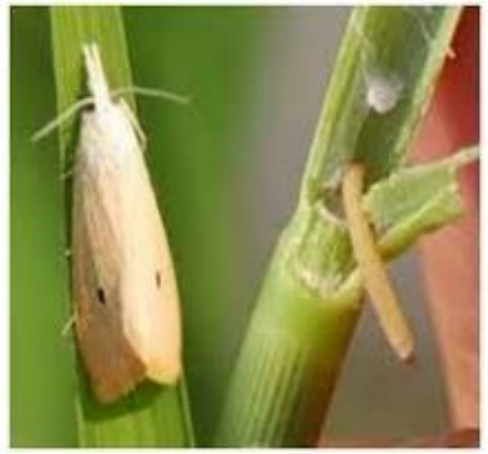

Gbr 10. kupu-kupu sundep

\section{KESIMPULAN DAN SARAN}

\section{A. Kesimpulan}

Adapun kesimpulan pada penelitian ini, sebagai berikut :

1. Pada penelitian ini dilakukan 7 hari penelitian dengan daya terbesar yang dihasilkan panel surya yaitu pada hari ke-2 pukul 11:00 WIB dengan daya sebesar 126,132 Watt, dan tegangan pada hari ke-2 yaitu $23,6 \mathrm{~V}$ dan arus sebsar 6,87 A. P

2. Pada penelitian ini terdapat 4 jenis hama yang terperangkap pada jaring - jaring kawat bertegangan yaitu hama wereng, walang sangit, lembing dan kupu - kupu sundep. Hama tersebut dapat merusak padi dan menyebabkan gagal panen.

3. Alat perangkap hama serangga pada tanaman padi dengan sumber panel surya dapat mengurangi bahan kimia yang biasa digunakan para petani dan menggunakan alat ini dapat membasmi hama serangga sehingga panen padi dapat berhasil.

\section{B. Saran}

Adapun saran yang dapat peneliti berikan, sebagai berikut :

1. Pada penelitian selanjutnya dapat dilakukan pengembangan yaitu menggunakan lampu yang mempunyai daya yang lebih besar, daya lampu yang digunakan pada penelitian ini hanya sebesar 10 Watt.

2. Pada penelitian selanjutnya dapat dilakukan pengembangan yaitu untuk menambahkan ketinggian pada alat sehingga lampu dapat mencakup area persawah yang cukup luas.

\section{REFERENSI}

[1] A. Julisman, I. D. Sara, And R. H. Siregar, "Prototipe Pemanfaatan Panel Surya Sebagai Sumber Energi Pada Sistem Otomasi Stadion Bola," Kitektro, Vol. 2, No. 1, Pp. 35-42, 2017.

[2] D. Pramana, D. P. Nugraha, And H. Prasetya, "Alat Teknologi Pendeteksi Dan Pembasmi Hama Wereng Berbasis Smartphone,” J. Sci. Pinisi, Vol. 3, No. 2, Pp. 93-97, 2017,

[3] G. Rudi Cahyono And N. Nurmahaludin, "Rancang Bangun Sistem Monitoring Populasi Hama Tanaman Padi Berbasis Web Dan Gateway," Poros Tek., Vol. 8, No. 2, P. 55, 2017, Doi: 10.31961/Porosteknik.V8i2.388.

[4] D. A. Siregar And H. Hambali, "Alat Pembasmi Hama Tanaman Padi Otomatis Berbasis Mikrokontroler Menggunakan Tegangan Kejut Listrik," Jtein J. Tek. Elektro Indones., Vol. 1, No. 2, Pp. 55-62, 2020, Doi: 10.24036/Jtein.V1i2.17.

[5] I. K. W. Gunawan, A. Nurkholis, And A. Sucipto, "Sistem Monitoring Kelembaban Gabah Padi Berbasis Arduino," J. Tek. Dan Sist. Komput., Vol. 1, No. 1, Pp. 1-7, 2020.

[6] S. Rumalutur And J. Ohoiwutun, "Sistem Kendali Otomatis Panel Penerangan Luar Menggunakan Timer Theben Sul 181 H Dan Arduino Uno R3," Electro Luceat, Vol. 4, No. 2, Pp. 43-51, 2018.

[7] Subandi, "Pembasmi Hama Serangga Menggunakan Cahaya Lampu Bertenaga Solar Cell," Vol. 9, No. 1, Pp. 86-92, 2016. 